\title{
Lepidoptera fauna of Namibia. I. Seasonal distribution of moths of the Koakoland (Mopane) Savanna in Ogongo, northern Namibia
}

\author{
Grzegorz KOPIJ \\ Department of Wildlife Management, University of Namibia, Katima Mulilio Campus, Private Bag 1096, Katima \\ Mulilo, Namibia; e-mail: gkopij@unam.na
}

\begin{abstract}
During the years 2011-2013, moths were collected in Koakoland (Mopane) Savanna in the Cuvelai Drainage System, Ovamboland, northern Namibia. In total, 77 species from 13 families have been identified. Their seasonal occurrence in this habitat was also investigated, with most species recorded in wet season between September and April, but with clear peak in February and March. The family Noctuidae was by far the most speciose (38 recorded species), followed by Crambidae ( $8 \mathrm{spp}$.), Sphingidae (6 spp.) and Arctiidae (4 spp.). All other families were represented by 1-3 species. For each species listed date of collection is given, and data on its global distribution.
\end{abstract}

Key words: Lepidoptera, check-list, biodiversity, distribution, moths, Ovamboland

\section{INTRODUCTION}

According to recent quite precise estimate, there are 155181 species, 16650 genera and 121 families of Lepidoptera worldwide (Pouge 2009).

Lepidoptera fauna of Namibia has recently attracted attention of European entomologists. However, thorough surveys were conducted hitherto in a few areas only, such as Brandberg and Hobatere. The northern regions of the country were especially badly neglected. In southern Africa (south of Zambezi and Kunene Rivers) - 8511 species, 2368 genera and 89 families were recently catalogued (Vári et al. 2002). Respective figures for Namibia are 819 species, 445 genera and 50 families; with 121 species (14.8\%) endemic to the country (Barnard 1998). The largest family, Noctuidae, is represented by 1608 species and 459 genera in southern Africa (Vári et al. 2002), while in Namibia by 147 species and 79 genera (Barnard 1998). This comparison shows rather a poor state of knowledge of southern African Lepidoptera fauna, and even poorer in a country within this region, Namibia.

In the last two decades, moths were regularly collected and studied thoroughly only from a few sites in Namibia, such as Brandberg (Mey 2004ab, 2007) and Hobatere area (Braine 2002). Fragmentary information on Lepidopetera fauna (usually records of dozen or so common species) are available from many other sites (e.g. Oberprieler 1992a, 1992b, Jürgens et al. 2010). Recently, May (2011) has collected butterflies and moths from 80 sites in Namibia, but none of these sites was located in Ovamboland. Although his samplings were relatively representative, he has managed to identify, as most his predecessors, only dozen or so species from each site. In lepidopterological surveys, especially badly neglected were the northern regions of Namibia: Kaokoland, Ovamboland, Kavango and Zambezi (May 2011). This note constitutes, therefore, a contribution to the knowledge of Lepidoptera fauna in this parts of the country.

\section{STUDY AREA}

The study was conducted on UNAM Ogongo Campus. It is situated in the BIOTA Observatory 'Ogongo' within the Cuvelai Drainage System, c. 50 km NW of Oshakati, Outapi

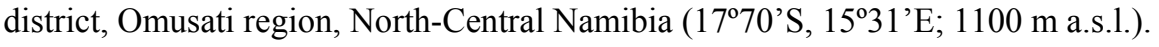


The BIOTA Transect and Biodiversity Observatories in Southern Africa is an international research project. It constitutes a transect which starts in the Cape Peninsula and runs through Western Cape, Northern Cape, and in Namibia through Oranjemund, Karios, Nabaos, Windhoek, Okahandja, Sonop and Mutompo, ending in Ogongo (Jürgens et al. 2010; Schmiedel \& Jürgens 2010; Hoffmann et al. 2010). In each of these observatories, both plant and animal diversities were subjects of a monitoring program. For some of these observatories, data on Lepidoptera diversity have been provided. However, in the BIOTA Observatory 'Ogongo' (S42), no such studies have been carried out (Jürgens et al. 2010; Schmiedel \& Jürgens 2010; Hoffmann et al. 2010).

The Ogongo area situated within the Cuvelai Drainage System is an extensive sandy plain, c. $1100 \mathrm{~m}$ a. s. 1., partly flooded almost annually (usually December-June). It is located in a prime summer rainfall zone, with mean annual precipitation of 400-500 $\mathrm{mm}$ (Mendelsohn et al. 2000). A total of 411 vascular plant species, 3 vegetation classes, 7 associations and 7 subassociations were described there (Kangombe 2007). The Cuvelai Drainage System comprises a network of hundreds of meandering oshanas (canals), separated by sodic sands covered with Koakoland Savanna (Mendelsohn et al. 2000). The system occupies $14773 \mathrm{~km}^{2}$; of which $5957 \mathrm{~km} 2$ is cleared or fenced, while $1926 \mathrm{~km} 2$ is transformed into cultivated land (Mendelsohn et al. 2000). In 2000, c. 563000 people inhabited this area. The climate is semiarid. Almost all rains (96\%) fall in summer (November-April), with two thirds in JanuaryMarch. The amount of rain varies from year to year, usually within 400-500 mm per annum (Mendelsohn \& Weber 2011). The average temperature of the coolest months (June-August) is $17^{\circ} \mathrm{C}$ and that of the warmest months (October-January) $25^{\circ} \mathrm{C}$.

The vegetation of dry land in the Ogongo area is dominated by shrubs and trees of Colophospermum mopane. Among fruit trees the most common are: morula Sclerocarya birrea, Berchemia discolor, Schinziophyton rautanenii and the makaloni palms Hyphaena petersiana. Other tree/shrub species which also occur in this vegetation are Acacia erioloba, A. nilotica, Zizyphus mucronata, Combretum spp., Ficus spp. (Jürgens et al. 2010). The vegetation of oshanas is dominated by grasses and sedges. On the margins, the most common species are Willkommia sermantosa, Eragrostis trichophora and Sporobolus iocladus; wetter places are occupied mainly by Eragrostis rotifer, E. viscose, Diplachne spp., Brachiaria deflexa, Elytrophorus globularis, and among sedges: Cyperus halpan, Kyllinga albiceps and Pycerus spp., Nymphaea spp. Further floating plants occur in deep open water (Mendelsohn \& Weber 2011).

\section{METHODS}

Moths were trapped by light 60W (cf. Kopij 2005). The light was set up in a rich mixed savanna close to university buildings on the UNAM campus. The sampling was made throughout the year from February 2011 to January 2013, almost on a daily basis. The collected moths were not counted, neither sexed, and were assigned to particular month, without exact date, as the purpose of the study was to provide a list of identified species for each month. The specimens were deposited in the zoological collection of the Department of Wildlife Management, UNAM, in Katima Mulilo.

As in Kopij (2005), for the identification of moth species Pinhey (1960, 1975), Picker et al. (2002) and Oberplierer (1995) were used, while the systematics, and nomenclature of all taxa follows that of Vari et al. (2002), as the most authoritative and comprehensive checklist of Lepidoptera of southern Africa. The new classification of Noctuidae, which treats the families Arctiidae, Lymanthriidae, Nolidae and Patheidae as subfamilies of the family of Noctuidae (Lafontaine \& Fibiger 2006), is not followed here. 
For each species listed (identified) month of collection and data on global distribution of the species are given. For each family and subfamily the number of genera (first number) and species (second number) known from southern Africa (after Vári et al. 2002) are given in brackets

\section{SYSTEMATIC REVIEW OF SPECIES}

\section{Cossoidea}

Cossidae $(7 / 15)$

\section{Azygophleps leopardina Distant, 1902}

Records: Feb-Mar 2011, Dec 2012.

Distribution: SA, Namibia, Zimbabwe, Zambia, northwards to Kenya.

Azygophleps asylas (Cramer, 1777)

Records: Apr 2012, Dec 2012.

Distribution: widespread in Africa.

\section{Zygaenoidea}

Limacodidae (58/119)

Limacodinae (54/104)

\section{Latoia latistriga (Walker, 1855)}

Records: Feb-Mar, common.

Distribution: southern Africa to Tanzania.

\section{Parapluda invitabilis (Wallengren, 1860)}

Records: Jan-March 2012, much darker than in the specimen depicted in Pinhey (1975) as \#107.

Distribution: all over southern Africa.

\section{Thyridoidea}

Thyrididae (=Hyblaeidae) (22/60)

Siculodinae $(13 / 28)$

\section{Cecidothyris pexa (Hampson, 1906)}

Records: common, Nov 2012, Apr 2012; the dark patter is not so clear as in the specimen depicted in Pinhey (1975) as \#137a.

Distribution: widespread in Africa.

\section{Pyraloidea}

Pyralidae (177/562)

Pyralinae (32/126) 
Records: Sep 2011.

Distribution: southern and eastern Africa.

Epipaschiinae (7/14)

Epilepia melanosparsalis (Janse, 1922)

Records: Jan 2013.

Distribution: southern Africa, DR Congo.

Epilepia melanobasis (Hampson, 1906)

Records: Records: Feb-Mar 2011.

Distribution: Transvaal, Zimbabwe, Zambia to DR Congo.

Crambidae (164/455)

Odontiinae (3/4)

Tegostoma subditale Zeller 1852 (=T. subditalis Hampson, 1896)

Records: Feb-Mar.

Distribution: southern and eastern Africa.

Pyraustinae (16/32)

Uresiphita gilvata (Fabricius, 1794)

Records: Jun-Jul 2011.

Distribution: Africa, southern Europe, western Asia.

Spilomelinae $(79 / 191)$

Bocchoris inspersalis (Zeller, 1852)

Records: Feb-Mar 2011.

Distribution: all over Africa and Asia.

\section{Ghesquierellana (=Botyodes) hirsutalis (Walker, 1859)}

Records: Sep 2011.

Distribution: southern and eastern Africa, Madagascar.

Diaphania indica $($ Saunders, 1851)=Glyphodes indica $($ Saunders, 1851)

Records: Jan 2013.

Distribution: all over Africa, Oriental Region, Australia.

Nausinoe geometralis (Guenée, 1854)

Records: Feb-March 2011.

Distribution: widespread in Africa, Asia and Australia.

Ischnurges lancinalis (Guenée, 1854)

Records: Dec 2012.

Distribution: southern Africa. 
Records: Feb-Mar.

Distribution: all over Africa.

\section{Geometroidea}

Geometridae (221/1105)

Geometrinae (59/171)

Allochrostes impunctata (Warren, 1897)

Records: Feb-Mar 2011.

Distribution: southern and equatorial Africa.

Comostolopsis stillata (Felder et Rogenhofer, 1875)

Records: Feb-March 2011.

Distribution: all over Africa.

Neromia strigulosa Prout, 1925

Records: Feb-March 2011.

Distribution: Namibia, Botswana, Zimbabwe, Free State.

Sterrhinae $(34 / 155)$

\section{Rhodometra sacraria (Linnaeus, 1767)}

Records: Dec. 2012.

Distribution: all over Africa, southern Europe.

Traminda vividaria (Walker, 1861)

Records: Jun-Jul 2011.

Distribution: all over Africa

Ennominae (94/594)

Chiasmia (=Semiothisa) rectilinea (Warren, 1905)

Records: Jun-July 2011.

Distribution: southern and eastern Africa.

\section{Bombycoidea}

Lasiocampidae (50/127)

Lasiocampinae (27/85)

Eutricha (=Pachypasa) sericeofasciata (Aurivillius, 1921)

Records: Nov 2012.

Distribution: southern and eastern Africa.

Sena (=Chilena) donaldsoni marshalli (Aurivillius, 1901)

Records: Dec 2012.

Distribution: southern and eastern Africa. 
Trichopisthia monteiroi (Druce, 1888)

Records: Jan 2013.

Distribution: southern Africa.

Saturniidae (29/75)

Athletes semialba (Sonthonnax, 1904)

Records: Jan. 2013.

Distribution: south-eastern Africa.

\section{Usta wallengrenii (Felder, 1969)}

Records: Jan 2013.

Distribution: southern and eastern Africa.

Sphingidae (48/105)

Macroglossinae (18/60)

\section{Basiothia medea (Fabricius, 1781)}

Records: Oct 2012, hind wings - orange, not yellow as in the specimen depicted in Pinhey (1975) as \#629; June-July 2011. Distribution: all over Africa.

\section{Hippotion celerio (Linnaeus, 1758)}

Records: Jan 2013, Dec 2012; last date: 3 Apr 2011.

Distribution: Africa, Europe and Oriental Region.

\section{Herse convolvuli (Linnaeus, 1758)}

Records: Jan-Mar 2012, Sep 2012.

Distribution: Africa, Eurasia, Australia; cosmopolitan.

\section{Hippotion eson (Cramer, 1779)}

Records: Feb-March 2011.

Distribution: all over Africa.

Hyles livornica (Esper, 1780) (=Celerio lineate livornica [Fabricius, 1775])

Records: Jan-Mar 2012.

Distribution: cosmopolitan.

\section{Rhodafra opheltes (Cramer, 1780)}

Records: Jan 2013.

Distribution: southern Africa.

\section{Noctuoidea}

Notodontidae (99/199)

Notodontinae (89/193)

Antheua encausta (Hampson, 1910)

Records: Feb-Mar 2011.

Distribution: southern and eastern Africa. 
Lymanthriidae (50/180)

Ruanda aetheria Strand, 1909.

Records: April 2011.

Distribution: Zimbabwe, Zambia, Tanzania.

Arctiidae (84/227)

Lithosiinae (40/91)

Argina amanda (Boisduval, 1847)

Records: June-July 2011.

Distribution: widespread in Africa.

Lithosia natara Moore, 1859

Records: Feb-Mar 2011.

Distribution: Africa, Eurasia.

Arctiinae (36/108)

Utetheisa pulchella (Linnaeus, 1758)

Records: Feb.-March 2011; Sept. 2011; Sept. 2012; Jan. 2013.

Distribution: all over Africa, Eurasia.

Eyralpenus testaceus (Walker, 1855) (=Diacrisia testacea [Walker, 1855])

Records: Feb-Mar 2011.

Distribution: southern and eastern Africa.

Noctuidae (459/1608)

Catocalinae

Acantholipes trimeni Felder et Rogehofer, 1874

Records: very common; Feb-Mar, Jun-Jul 2011.

Distribution: southern Africa.

Achaea catella Guenée, 1852

Records: Jan 2013.

Distribution: southern and eastern Africa.

Anomis sabulifera (Geuenée, 1852)

Records: Feb-Mar 2011.

Distribution: all over Africa and southern Asia.

Bamra marmorifera (Walker, 1858)

Records: Feb-Mar 2011.

Distribution: southern Africa.

\section{Cerocala vermiculosa Herrich-Schaeffer, 1854}

Records: Feb-Mar 2011, Sep 2011, Jan-Mar 2012, Oct 2012, Jan 2013; common. Distribution: southern Africa. 
Ctenusa varians (Wallengren, 1863) (=Acanthonyx marginalis [Walker, 1858])

Records: Sept 2011, Nov 2012; strips on forewing much darker than in a specimen depicted in Pinhey (1975) as \#1044.

Distribution: southern and eastern Africa.

\section{Cyligramma latona (Cramer, 1775)}

Records: Feb-March 2011, Dec 2012; very common, daily activity.

Distribution: all over Africa.

Eudocima (=Othreis) materna (Linnaeus, 1767)

Records: Jan 2013; Dec 2012.

Distribution: Africa, southern Asia, Australia.

Grammodes (=Caranilla) geometrica (Fabricius, 1775)

Records: Sept 2011, Jun-Jul 2011.

Distribution: Africa, Eurasia, Australia.

Grammodes (=Prodotis) stolida (Fabricius, 1775)

Records: common, Feb-March 2011; Jun-Jul 2011.

Distribution: Africa, Eurasia.

\section{Dysgonia algira (Linnaeus, 1767)}

Records: Dec 2012.

Distribution: all over Africa.

Mocis mayeri (Boisduval, 1833)

Records: Sep 2011.

Distribution: all over Africa.

Nagia sacerdotis Hampson, 1926

Records: Oct 2012.

Distribution: southern Africa.

Ophiusa tirhaca (Cramer, 1777)

Records: Jan 2013.

Distribution: Africa and Eurasia.

Pandesma (=Thria) robusta Walker, 1857

Records: Sep 2011.

Distribution: all over Africa, Middle East.

\section{Rhanidophora cinctigutta (Walker, 1862)}

Records: Jan-March 2012, spots without dark margins in comparison with the specimen depicted in Pinhey (1975) as \#1109; Dec 2012, Jan 2013.

Distribution: southern and eastern Africa.

Sphingomorpha chlorea (Cramer, 1777)

Records: Feb-Mar 2011, Sep 2012; common.

Distribution: Africa and Middle East. 
Trigonodes hyppasia (Cramer, 1779)

Records: Sep 2011.

Distribution: all over Africa.

Plusiinae (10/60)

Chrysodeixis acuta (Walker, 1858)

Records: Feb-Mar 2011; common.

Distribution: Africa, Oriental Region and Australia.

Chloephorinae (16/48)

Arcyophora longivalvis Guenée, 1852

Records: Feb-Mar 2011.

Distribution: southern and eastern Africa.

\section{Earias biplaga Walker, 1866}

Records: Feb-Mar 2011.

Distribution: all over Africa.

Xanthodes graellsii (Feisthamel, 1837)

Records: Feb-Mar 2011; Dec 2012.

Distribution: all over Africa.

Sarrothripinae (14/32)

Nycteola (=Sarrothripus) malachitis (Hampson,1912)

Records: Feb-Mar 2011.

Distribution: southern and eastern Africa.

Nolinae $(7 / 37)$

Nola leucalea Hampson, 1907

Records: May 2011.

Distribution: southern and eastern Africa.

Acontiinae (52/261)

Eublemma anachoresis (Wallengren, 1863)

Records: common, Feb-Mar 2011; Dec 2012.

Distribution: Africa, Asia, Australia.

Ozabra heliastis (Hampson, 1902)

Records: Sep 2011.

Distribution: southern and eastern Africa.

Tarache guttifera Felder et Rogehofer, 1874

Records: Nov 2012; whitish, not yellowish as the specimen depicted in Pinhey (1975) as \#1180.

Distribution: southern and eastern Africa. 
Records: Dec 2012.

Distribution: all over Africa.

Agaristinae (19/33)

\section{Lophonotidia nocturna Hampson, 1901}

Records: Feb-Mar 2011.

Distribution: southern Africa to Tanzania.

Acronictinae (4/7)

Athetis leucopis (Hampson, 1902)

Records: Apr 2011; much darker than the specimen depicted in Pinhey (1975) as \#962.

Distribution: Cape only.

Amphipyrinae (91/324)

Leumicamia (=Mimleucania) leucosoma (Felder et Rogenhofer, 1874)

Records: Dec 2012.

Distribution: southern Africa, Madagascar.

\section{Spodoptera littoralis (Boisduval, 1833)}

Records: Sep 2012.

Distribution: all over Africa.

Ramesodes divisa (Hampson, 1902)

Records: Feb-March 2011.

Distribution: South Africa.

Cuculliinae $(16 / 50)$

Cucullia (=Empusada) hutchinsoni Hampson, 1902

Records: Sep 2012; forewing - light grey-yellow in comparison with the specimen depicted in Pinhey (1975) as \#914; Dec 2012.

Distribution: southern Africa.

Noctuinae $(15 / 68)$

Agrotis biconicus (=spinifera) (Huebner, 1808)

Records: Jun-July 2011.

Distribution: all over Africa, Eurasia.

Effrectilis (=Agrotis) effracta (Distant, 1898)

Records: May 2011.

Distribution: southern Africa.

Heliothinae (6/29)

Masalia (=Timora) laceolata (Walker, 1865)

Records: Feb-March 2011.

Distribution: all over Africa and the Middle East. 


\section{Adisura aerugo (Felder et Rogenhofer, 1874)}

Records: Dec 2012.

Distribution: southern Africa.

\section{SUMMARY}

In total, 77 species from 13 families have been identified (Table 1). The family Noctuidae was by far the most speciose ( 38 recorded species), followed by Crambidae ( 8 spp.), Sphingidae (6 spp.) and Arctiidae (4 spp.). All other families were represented by 1-3 species.

Most species were recorded in wet season between September and April, but the highest richness was obtained in February (35) and March (46).

The presented study lists only a small fraction of the lepidopteran diversity in these regions. In lepidopterological syrveys in Namibia, the northern regions were hitherto badly neglected. Further studies are, therefore, highly recommended

Table 1. Monthly occurrence of moths in Kaokoland savanna in Ogongo.

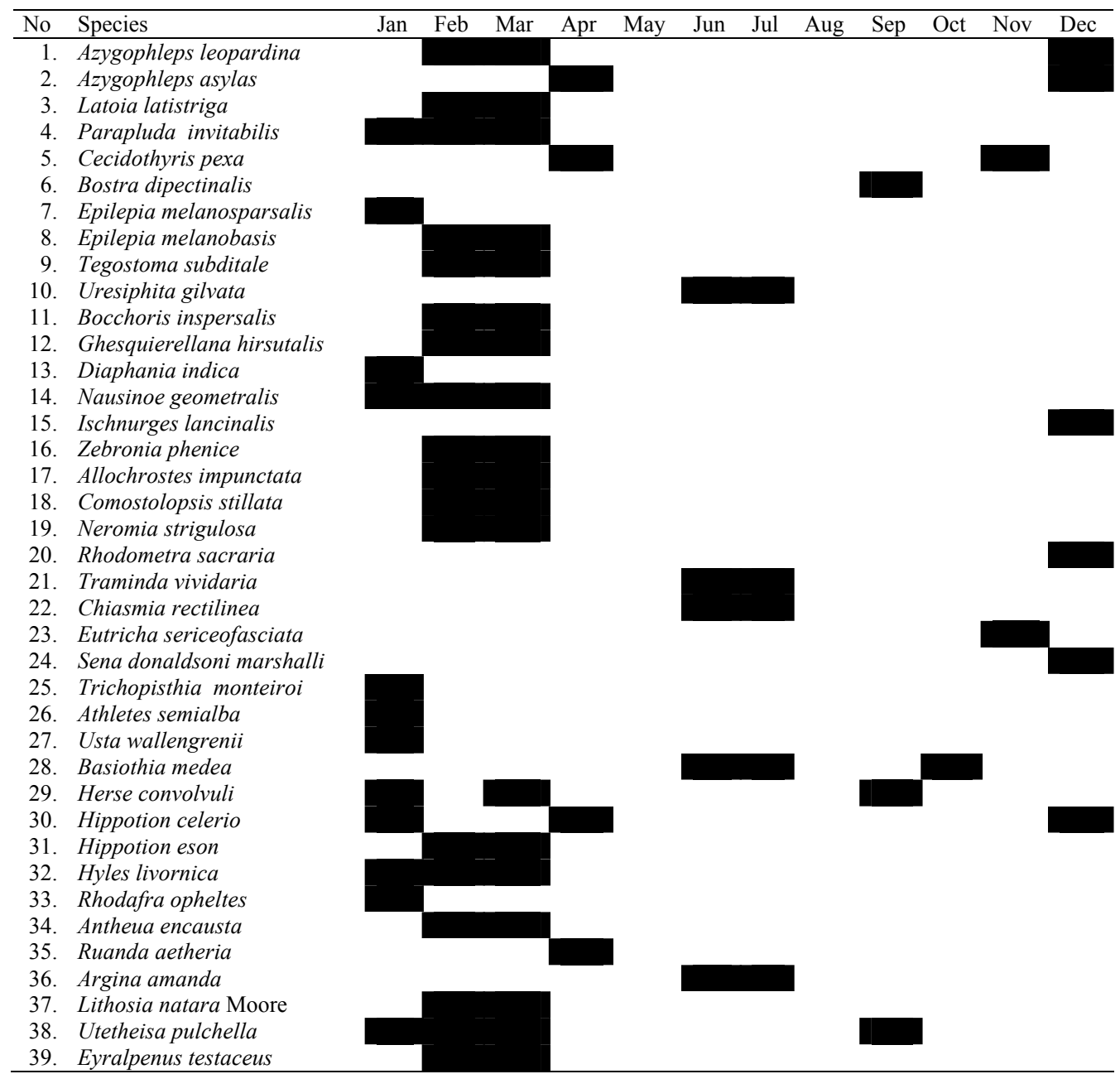




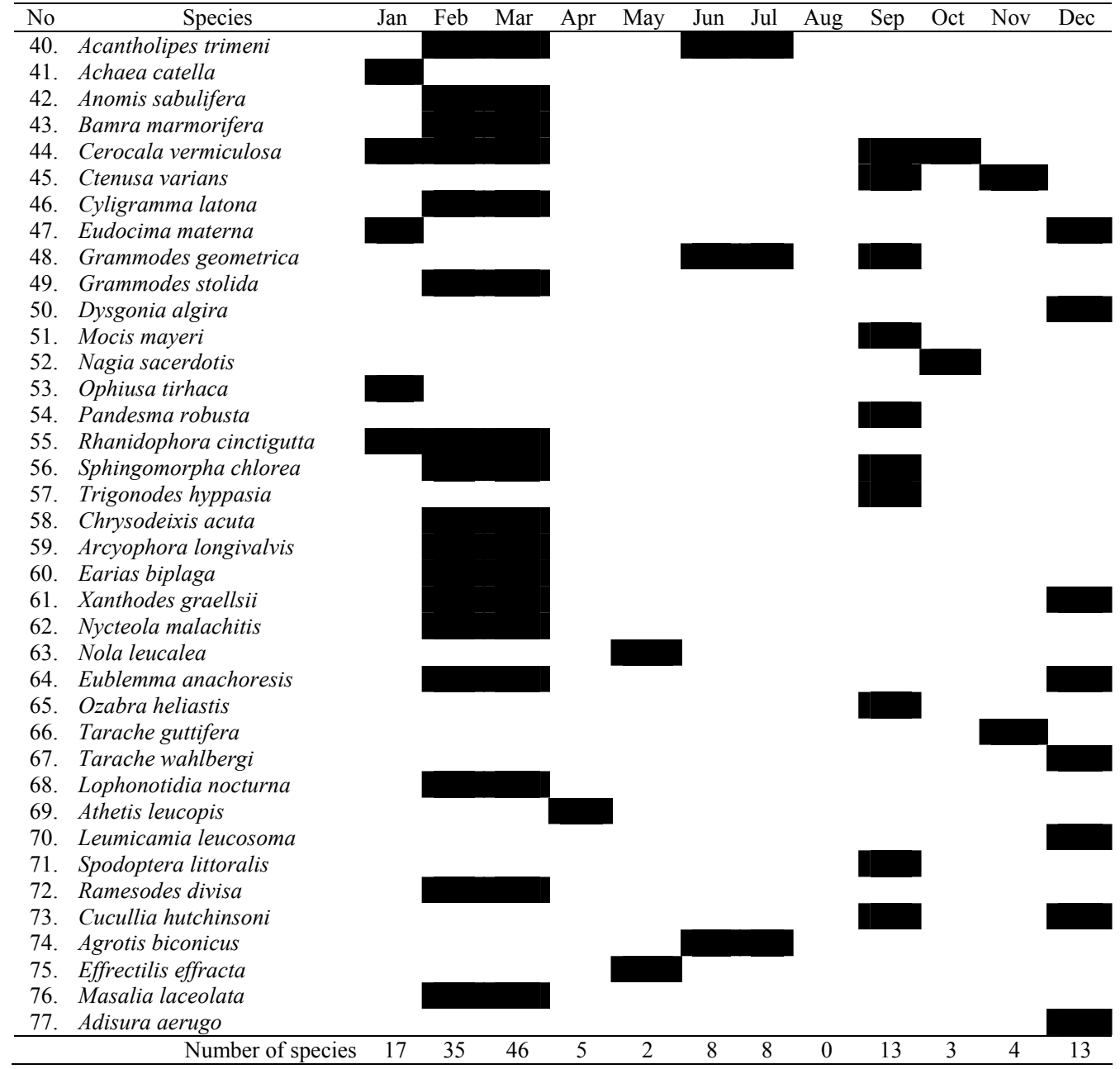

\section{REFERENCES}

BARNARD P. (ed.) 1998. Biological diversity in Namibia: a country study. Namibian National biodiversity Task Force, Windhoek, $332 \mathrm{pp}$.

BRAINE S. 2002. Another lindae? And checklist of butterflies from the Hobatere cConcession Area, Namibia. Metamorphosis 13 (4): 116-121.

HofFMAN M. T., SCHMIEDEL U. \& JÜRGENS N. 2010 (eds). Biodiversity in southern Africa. Volume 3: Implications for land use and management. Göttingen \& Windhoek: Klaus Hess Publishers, 109-150 pp.

JÜrgens N., HaArmeyer D. H., Luther-Mosebach J., Dengler J., Finckh M. \& Schmiedel U. 2010 (eds). Biodiversity in southern Africa. Volume 1: Patterns at local scale - the BIOTA Observatories. Göttingen \& Windhoek: Klaus Hess Publishers, 6-801 pp.

KANGOMBE F. N. 2007. Vegetation description and mapping of Ogongo Agricultural College and the surrounds with the aid of satellite imagery. B.Sc. Thesis. University of Pretoria, Pretoria.

KoPIJ G. 2005. Lepidoptera fauna of Lesotho. Acta Zoologica Cracoviensia, 49B: 137-180.

LAFONTAINE J. D. \& FiBIGER M. 2006. Revised classification of Noctuidae (Lepidoptera). Canadian Entomologist 138: 610-635.

Mendelsohn J., el OBeid S. \& Roberts C. 2000. A profile of north-central Namibia. Windhoek: Gamsberg Macmillan Publishers, 79 pp. 
Mendelsohn J. \& Weber B. 2011. The Cuvelai Basin, its water and people in Angola and Namibia. Occasional Paper no. 8. Luanda: Development Workshop, $120 \mathrm{pp}$.

MEY W. 2004a. Introduction: research on Lepidoptera of the Brandberg in Namibia (Insecta, Lepidoptera). Esperiana Memoir 1: 7-26.

MEY W. 2004b. Lepidoptera Africana part 1: the Lepidoptera of the Brandberg Massif in Namibia part 1. Esperiana Memoir 1: 1-362.

MEY W. 2007. The Lepidoptera of the Brandberg Massif in Namibia part 2. Esperiana Memoir 4: 1-303.

MAY W. 2011. Basic pattern of Lepidoptera diversity in southwestern Africa. Esperiana Memoir, 6: 7-314

OBERPRIELER R. 1992a. Die Nachtpfauenaugen (Saturniidae) Suwestafrikas [sic]. 9. Die Arten aus dem KavangoCaprivi-Gebiet. Mitteilungen Namibia Wissenschaftliche Gesellschaft 33 (9-10): 115-125.

OBERPRIELER R 1992b. Die Nachtpfauenaugen (Saturniidae) Sudwestafrikas. 10. Erganzunzungen und Korrekturen zur Serie, mit Artenliste der Saturniidae des Landes. Mitteilungen Namibia Wissenschaftliche Gesellschaft, 33 (910): $125-130$

OBERPRIELER R. 1995. The emperor moths of Namibia. Ekogilde Pubs, Hartbeespoort (South Africa), 104 pp.

PiCKer M., Griffiths C. \& WeAving A. 2002. Field guide to insects of South Africa. Struik Publishers, Cape Town, $456 \mathrm{pp}$.

PINHEY E. C. G. 1960. Hawk moths of central and southern Africa. Longmans, Cape Town, 139 pp.

PinHEY E. C. G. 1975. Moths of southern Africa. A. A. Balkema, Rotterdam, 273 pp.

Pouge M. G. 2009. Biodiversity of Lepidoptera. In: FootTit R. G., ADLER P. H. (eds), Insect biodiversity. Science and Society, pp. 325-355. Willey-Blackwell, Oxford.

Schmiedel U. \& JÜRgens N. 2010 (eds). Biodiversity in southern Africa. Volume 2: Patterns and processes at regional scale, pp. 118-135. Klaus Hess Publishers, Göttingen \& Windhoek.

VÁRI L., KROON D. M. \& KRÜGER M. 2002. Classification and checklist of the species of Lepidoptera recorded in southern Africa. Simple Solution, Chatswood (Australia), 385 pp.

\section{STRESZCZENIE}

\section{[Motyle (Lepidoptera) Namibii. I. Sezonowe rozmieszczenie ciem na sawannie Koakoland (Mopane) w Ogongo (północna Namibia)]}

Badania prowadzono w latach 2011-2013 na sawannie porośniętej Acacia erioloba w Cuvelai Drainage System, Ovamboland w północno-środkowej Namibii. W sumie znaleziono 77 gatunków ciem z 13 rodzin. Największe bogactwo gatunkowe reprezentowała rodzina Noctuidae (38 gatunków), w porównaniu z Crambidae (8 gatunków), Sphingidae (6 gatunków) i Arctiidae (4 gatunki). Pozostałe rodziny były reprezentowane przez 1-3 gatunki. Dla każdego gatunku podano datę znalezienia i dane dotyczące globalnego rozmieszczenia. 